\title{
Potential of biogas production from anaerobic co-digestion of fat, oil and grease waste and food waste
}

\author{
Reigina Sandriaty ${ }^{1}$, Cindy $_{\text {Priadi }^{1}}{ }^{*}$, Septiana Kurnianingsih ${ }^{1}$, and Ayik Abdillah ${ }^{1}$ \\ ${ }^{1}$ Environmental Engineering Study Program, Civil Engineering Department, University of Indonesia, Depok, Indonesia, 16424
}

\begin{abstract}
The generation of fat, oil and grease (FOG) waste can be a nuisance hazard, but also a potential for resource recovery. FOG waste can be utilized as nutrient and energy source through anaerobic digestion which may increase methane yield but also increase presence of inhibitors. Using the biochemical methane potential method, this research is aimed to determine the effect of FOG waste in the co-digestion process of food waste (FW) to produce biogas. The research was conducted for 42 days at $37^{\circ} \mathrm{C}$ using FOG waste codigested with FW of 3 different volatile solid (VS) rasio which are $0.125,0.3$, and 0.5 . The results showed that FOG waste combined with FW has a methane yield that may reach up to $485 \pm 36.8 \mathrm{~mL} \mathrm{CH} / / \mathrm{gr} \mathrm{VS}$, the highest one produced by the $0.125 \mathrm{VS}$ rasio mix. While the ratio of FOG waste with FW at 0.3 and 0.5 only produce $128 \pm 195$ and $4 \pm 1.45 \mathrm{~mL} \mathrm{CH}_{4} / \mathrm{gr}$ VS, respectively. The ratio of 0.125 also demonstrates the highest COD reduction of $56 \%$ compared to the other ratio which indicates the $0.125 \mathrm{FOG}$ and $\mathrm{FW}$ ratio can be implemented to utilize FOG waste and increase methane yield during anaerobic digestion process.
\end{abstract}

\section{Introduction}

Fat oil and grease (FOG) waste is a by-product of cooking process [1] and generally consists of food losses, fatty meat, cooking oil, butter, margarine, sauce, gravy, fried food, cheese, etc. [2]. Consumption pattern of society shifted towards fast food that uses a lot of oil. In 2015, restaurant industries grew 3.89 percent indicated FOG waste was raised [3].

To manage FOG waste, several countries in Southeast Asia dispose FOG waste directly to the environment without being processed. In Malaysia where the population tend to consume food containing fat and oil, FOG waste is still discharged directly to the sewage system [1]. In Bangkok City, Thailand, most of the FOG waste is also discharged directly to the sewage system or collected in grease trap unit then disposed to the landfill by open dumping with other solid organic waste [4].

FOG waste generated from food processing and other activities such as dishwashing from various food provider facilities have the potential of causing environmental problems. FOG waste is classified as complex and heterogeneous wastes [5] that renders it difficult to be decomposed biologically with conventional processing due to its consistency [4]. In 2010, more than 22,000 sewer in Malaysia was clogged and $98 \%$ of them was caused by FOG waste [1]. Even in developed countries such as USA and UK, the sediment from FOG waste was reported to be the cause of sewer overflow [6,7]. FOG waste also have the potential of causing mechanical disruption, the possibility of emergence inhibitor, the difficulty of oxygen transfer and odor problems [5] in wastewater treatment plant. The problem should be avoided because of the risk of disturbing public health [8], potentially polluting water bodies, groundwater, and disrupting the habitat of fish and other wildlife [1].

Several previous studies treating FOG waste have been conducted. To maximize the potential of FOG waste, it is commonly used as co-substrates in the anaerobic co-digestion process. From previous research in the co-digestion process between the sewage sludge and the FOG waste, it was found that the addition of sludge from the $10-30 \%$ fat catcher unit proved to increase methane gas yield by $9-27 \%[9,10]$. Other codigestion studies between organic fractions of municipal solid waste as well as FW combined with the FOG waste also showed that there is an increase in methane gas produced with the addition of the FOG waste by about $46 \%$ in the anaerobic digestion process with the addition of $15 \%$ oil waste based on VS value [6].

On the other hand, the used of FOG waste in the anaerobic co-digestion process has its own challenges associated with the potential inhibitors produced in the form of high volatile fatty acids and the formation of long-chain fatty acids in the startup process. However, the inhibitors are non-fixed [11] but can be prevented with adaptation of anaerobic cultures [12], and careful consideration of the ratios used in the digestion process to avoid excessive organic loading [13].

Therefore, this research is aimed to quantify the potential and proportion of FOG waste in producing biogas through co-digestion process with organic waste substrate composed mostly by FW using the biochemical methane potential (BMP) method.

\footnotetext{
*Corresponding author: cindy.priadi@eng.ui.ac.id
} 


\section{Materials and Methods}

\subsection{Inoculum}

The inoculum used in this experiment originated from an anaerobic digestion plant at Petamburan Market treating organic waste. The inoculum was acclimatized in an anaerobic environment during 35 days by adding organic waste with Cow Manure (CW) which will be the substrate used in this study in order to adapt the bacteria to the substrate because the FOG waste can potentially release long chain fatty acids that cause inhibitory effects [14]. Substrate with increasing organic loading is added every 7 days with the number of feeding are $10 \%$ of the total liquid in the container. $\mathrm{pH}$ measurement was done regularly to maintain ideal environmental condition for microorganism inside inoculum. If the $\mathrm{pH}$ value reached below 6 , then $\mathrm{NaHCO}_{3}$ was added as buffer solution with $3 \mathrm{gr} /$ Liter inoculum dosage. Acclimatization of inoculum lasted during 35 days demonstrated $\mathrm{pH}$ that remained between 6 and 6.5 indicating an ideal condition to use the inoculum for the BMP experiment.

\subsection{Substrate}

The substrate used for BMP experiment was a mixture of organic waste consisting mostly of FW and CM with 9:1 $(\mathrm{w} / \mathrm{w})$ ratio, concluded after a previous research [15]. The organic waste consists of food losses and FW collected from Universitas Indonesia's canteen. The FW in UI has been found as an effective feedstock of anaerobic digestion [16] and the CM was from a nearby farm. The organic waste collected was sorted and shredded into 2-3 $\mathrm{mm}$ [17] while the CM was not pretreated. The FW and CM was taken once as needed and stored in the airproof plastic bag to be taken to the laboratory.

\subsection{Co-substrate}

The co-substrate was FOG waste from the grease trap of canteen of Faculty of Engineering, Universitas Indonesia (Fig.1). The canteen consisted mostly of Asian cuisine prepared by frying. The FOG waste samples used were composite samples obtained from sampling on 2 different days.

\subsection{Biochemical Methane Potential (BMP)}

The procedure of BMP used was based on Angelidaki et al (2009) with three variations of substrate and cosubstrate mixture. The VS ratio of the mixture of FOG waste to $\mathrm{FW}$ and $\mathrm{CM}$ in this BMP experiment were $0.125 ; 0.3$; and 0.5 . In brief, the experiment was conducted in $125 \mathrm{~mL}$ bottles, with $50 \mathrm{~mL}$ of mixture and $75 \mathrm{~mL}$ headspace. Each sample mixture was experimented in triplicates and accompanied with blanks (inoculum only) and control (with known standard). The experiment was conducted until daily gas production increase was less than $2 \%$ per day.

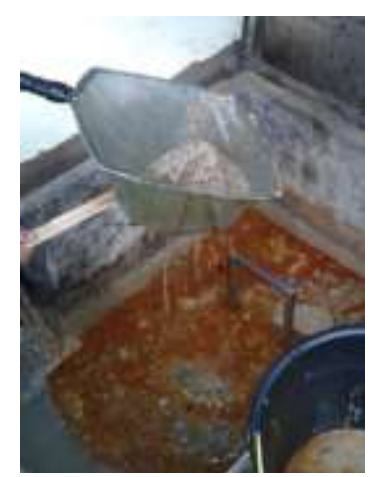

Fig. 1. The FOG Waste from Engineering Faculty Canteen

\subsection{Analytical Methods}

Substrates and mixtures were analyzed prior and after the BMP experiment. The parameters tested for the liquid solution included COD, TS, VS, and FOG content of each mixture. Meanwhile, the biogas was analyzed every 7 days using a flow sensor and the biogas composition was measured using gas chromatography.

\section{Results and Discussions}

\subsection{Mixture Characteristics of BMP Experiment}

Table 1. Characteristics of Substrate and Co-substrate

\begin{tabular}{|c|c|c|c|c|c|c|}
\hline \multirow{2}{*}{ Samples } & TS & VS & VS/TS & COD & FOG & \multirow{2}{*}{ C/N } \\
\cline { 2 - 6 } & $\mathbf{g} / \mathbf{L}$ & $\mathbf{g} / \mathbf{L}$ & $\mathbf{\%}$ & $\mathbf{g} / \mathbf{L}$ & $\mathbf{g} / \mathbf{L}$ & \\
\hline FW and CM & 181 & 161 & 99 & 188 & 1,87 & 3,26 \\
\hline FOG & 763 & 759 & 99 & 148 & - & 28,9 \\
\hline Inoculum & 38,4 & 24,6 & 64 & 30,9 & 0,39 & - \\
\hline
\end{tabular}

The composite FOG waste used in this experiment had $148 \mathrm{~g} / \mathrm{L}$ COD (Table 1), greater than the COD value of waste water from Thai restaurants and Asian food which in the literature has a COD value in the range of 8.1 to $21.3 \mathrm{~g} / \mathrm{L}$ [18]. However, oil and fat waste originating from restaurants in the United States can range from 138 to $910 \mathrm{~g} / \mathrm{L}$. Significant differences in COD values between the FOG waste in this study with the literature can occur due to differences in sources of FOG waste and types of processed foods.

Meanwhile, the VS value of FOG waste composite was high, up to $759 \mathrm{~g} / \mathrm{L}$ with ratio VS/TS was $99 \%$. The VS value of FW from canteen was $85 \mathrm{~g} / \mathrm{L}$ and $95 \%$ $\mathrm{VS} / \mathrm{TS}$ which is in accordance with the literature where the $\mathrm{FW}$ from the canteen has a range of VS/TS values of 90-95\%. 


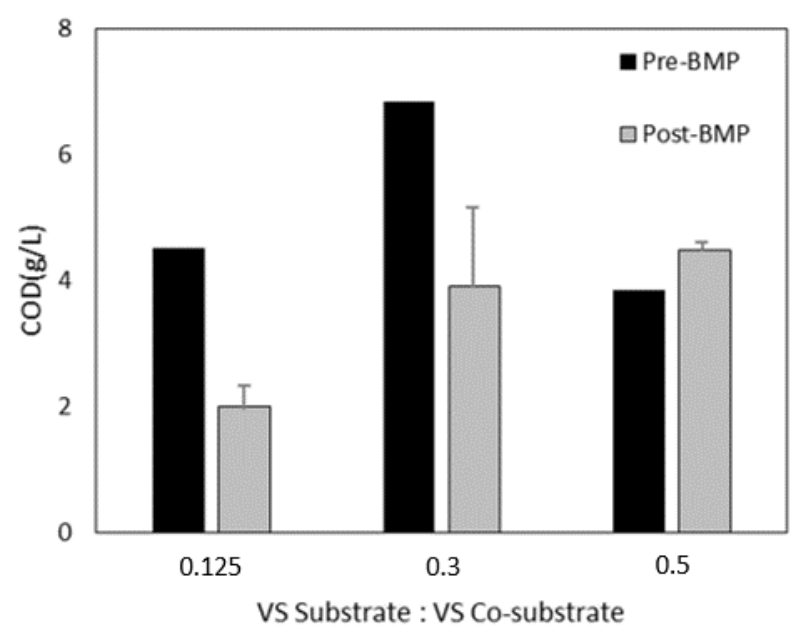

Fig. 3. The COD Value of BMP Experiment

\subsection{BMP Experiment}

The COD value during pre-BMP for FOG to FW-CM ratio of $0.125 ; 0.3$; and 0.5 were $4.52 ; 6.83$; and $3.85 \mathrm{~g} / \mathrm{L}$ COD respectively (Fig. 3). Based on these data, it can be observed that in the 0.125 and 0.3 ratio, the COD value at the beginning of BMP test process was directly proportional to the amount of FW waste addition. In the ratio of 0.5 , the COD value showed smallest among the three data.

The VS values at the beginning of BMP for ratio $0.125 ; 0.3$; and 0.5 were $5.05 \pm 0.8 ; 4.50 \pm 0.1$; and 4.12 \pm 0.6 , respectively and at the end of the BMP test, VS test was performed with results of $4.29 \pm 0.3 ; 5.79 \pm 1.8$; and $6.89 \pm 1.0$, respectively (Fig 4).

After going through the incubation process under anaerobic conditions for 42 days, a COD was tested at the end of the BMP test. The test results showed that in the ratio of 0.125 and 0.3 , the decrease of COD was positive, each with an efficiency of $55.9 \%$ and $44.8 \%$, respectively. Meanwhile, the COD in 0.5 rasio increased. Only the ratio of 0.125 shows a positive VS destruction (VSD) of $15 \%$. While for the ratio of 0.3 and 0.5 , the VS also increased. The reason to this phenomenon may be similar to the reason of the COD increase as mentioned above. The increase of COD value on the ratio of 0.5 could be caused by the emergence of SCOD after BMP test that was more easily detected by the COD and VS analytical method compared to the COD and VS before BMP test.

\subsubsection{Volatile Fatty Acid (VFA) and Lipid Content}

The VFA/TA (Total Alkalinity) was observed on each BMP mixture in the end of the BMP process. The VFA/TA value for $0.125 ; 0.3$; and 0.5 ratio obtained were $0.220 \pm 0.115 ; 0.617 \pm 0.365$; and $1.09 \pm 0.534$, respectively. Based on this result, the 0.3 ratio showed process instability due to the VFA value beyond the stability limit in the literature (0.3) [19]. Meanwhile, at the 0.5 ratio indicated a process failure because the VFA value exceed 0.8 .

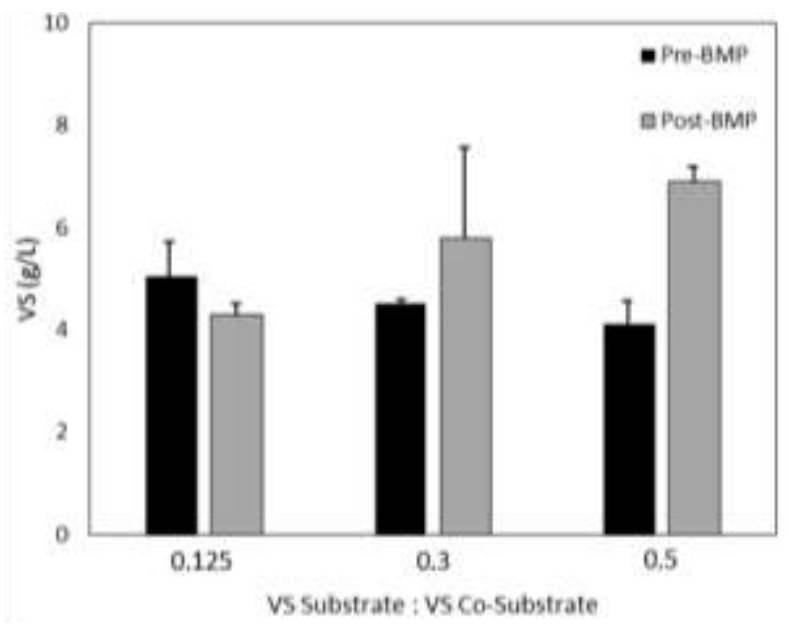

Fig. 4. The VS Value of BMP Experiment

The FOG content in BMP mixtures was inversely proportional to the amount of FOG for waste added, with a value of $1.89,0.64$ and $0.39 \mathrm{~g} / \mathrm{L}$ for ratio $0.125 ; 0.3$; and 0.5 , respectively. This suggests that there was a possibility that the mixture of FW and cow dung and inoculum also contain significant amounts of FOG. Indeed, anaerobic co-digestion between organic fractions of municipal solid waste with FOG waste by using batch reactor demonstrated that FOG waste addition of $15 \%$ VS and $35 \%$ can decrease lipid content by $42 \pm 3$ and 34 $\pm 1 \%[5]$.

\subsubsection{Methane Yield}

The highest yield of cumulative biogas was produced by variation of ratio of 0.125 with the addition of the least FOG waste. Methane yield obtained from the ratio of $0.125 ; 0.3$; and 0.5 , respectively were $485 \pm 36.8 \mathrm{~mL}$, $128 \pm 195 \mathrm{~mL}$, and $4 \pm 1.45 \mathrm{~mL} \mathrm{CH}_{4} / \mathrm{gr}$ VS. The high methane yield of 0.125 ratio is in line with the VS reduction of $16.5 \%$ (higher than 0.3 and 0.5 ratio). The methane yield is also associated with the VFA value. Under certain conditions the interaction between total ammonia, VFA, and $\mathrm{pH}$ can lead to inhibited steady state which is a condition where the process is stable but with low methane yield [20].

The previous research on anaerobic co-digestion process between FOG waste with organic fraction of urban solid waste resulting $550 \mathrm{~mL} \mathrm{CH}_{4} / \mathrm{gr}$ VS [21] is similar to this research. Although FW and FOG waste in each country differ, this experiment demonstrates that these substrates can be combined to optimize the process of anaerobic digestion. 


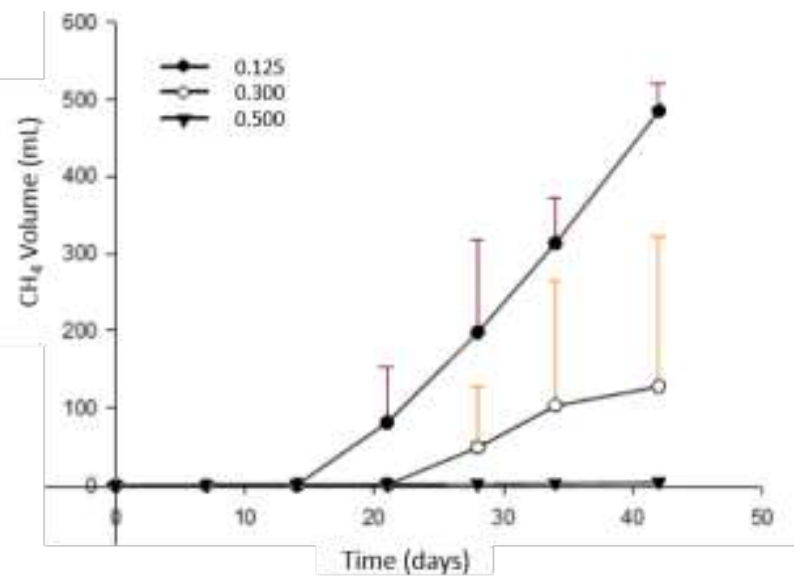

Fig. 5. Methane yield FOG Waste vs Mixture of Food Waste And Cow Mannure

\section{Conclusion}

The anaerobic co-digestion process of FOG waste with FW and CM experimented with the biochemical methane potential method produced the highest methane yield at $485 \mathrm{~mL} \mathrm{CH}_{4} / \mathrm{gr} \mathrm{VS}$ and the highest COD reduction of $16.5 \%$ with ratio VS FOG waste with VS waste of food and CM equal to 0.125 .

Acknowledgements to Universitas Indonesia for financially supporting this research by Grant of Indexed International Publications for Student Final Project (Hibah PITTA), No. 2408/UN2.R3.1/HKP.05.00/2018.

\section{References}

1. Indah Water Konsortium Sdn Bhd. 2010. Sustainability Report.

2. Husain, I. A. F., Alkhatib, F., Jammi, M. S., Mirghani, M. E. S., Zainudin, Z. Bin, \& Hoda, A. . Problems, Control, and Treatment of Fat, Oil, and Grease (FOG ): A Review. Journal of Oleo Science, 752(8), 747 - 752. (2014)

3. Rangkuti F. Y and Whrigt T. Indonesia Food Service - Hotel Restaurant Institutional. New York: USDA Agricultural Foreign Service. (2016).

4. Martín-González, L., Colturato, L. F., Font, X., \& Vicent, T. Anaerobic co-digestion of the organic fraction of municipal solid waste with FOG waste from a sewage treatment plant: Recovering a wasted methane potential and enhancing the biogas yield. Waste Management, 30(10), 1854 - 1859. (2010).

5. Keener, K. M., Ducoste, J. J., \& Holt, L. M. Properties Influencing Fat, Oil, and Grease Deposit Formation. Water Environment Research, 80(12), 2241 - 2246. (2008).

6. Department for Environment Food and Rural Afair UK, W. U. Disposal of Fats, Oils, Grease, and Food Waste Best Management Practice for Catering Outlets Working in partnership with : Fat, Oil and Grease in Drains. Best Management Practive for Catering Outlets. (2007).
7. Aziz, T. N., Holt, L. M., Keener, K. M., Groninger, J. W., \& Ducoste, J. J. Performance of Grease Abatement Devices for Removal of Fat, Oil, and Grease. Journal of Environmental Engineering, 137, 84 - 92. (2011)

8. Davidsson, Å., Lövstedt, C., la Cour Jansen, J., Gruvberger, C., \& Aspegren, H. Co-digestion of grease trap sludge and sewage sludge. Waste Management, 28(6), 986 - 992. (2008).

9. Pereira, M. a., Sousa, D. Z., Mota, M., \& Alves, M. M. Mineralization of LCFA associated with anaerobic sludge: Kinetics, Enhancement of Methanogenic Activity, and Effect of VFA. Biotechnology and Bioengineering, 88(4), 502-511. (2004)

10. Silvestre, G., Rodríguez-Abalde, a., Fernández, B., Flotats, X., \& Bonmatí, A. Biomass Adaptation Over Anaerobic Co-Digestion Of Sewage Sludge And Trapped Grease Waste. Bioresource Technology, 102(13), 6830 - 6836. (2011).

11. Neczaj, E., Bien, J., Grosser, A., Worwag, M., \& Kacprzak, M. Anaerobic Treatment of Sewage Sludge and Grease Trap Sludge in Continuous CoDigestion. Global Nest Journal, 14(2), 141 - 148. (2012).

12. Angelidaki, I., Alves, M., Bolzonella, D., Borzacconi, L., Campos, J. L., Guwy, A. J., Lier, J. B. Van. Defining The Biomethane Potential ( BMP) Of Solid Organic Wastes And Energy Crops : A Proposed Protocol For Batch Assays. Water and Science Technology, IWA Publishing, 59(5), 927934. (2009).

13. Alves, M. M., Pereira, M. A., Sousa, D. Z., Cavaleiro, A. J., Picavet, M., Smidt, H., \& Stams, A. J. M. Waste Lipids to Energy: How to Optimize Methane Production From Long-Chain Fatty Acids (LCFA). Microbial Biotechnology, 2(5), 538-550. (2009).

14. Al Seadi, T., Rutz, D., \& Janssen, R. Biomass Resources For Biogas Production. Science, Production, and Applications. Woodhead Publishing Series in Energy, 19 - 51. (2013).

15. Theresia, M. \& Priadi, C.R. Optimization of Methane Production by Combining Organic Waste and Cow Manure as Feedstock in Anaerobic Digestion. AIP Conference Proceedings, 1826(1). (2017)

16. Wulansari, B., \& Kristanto, G. A. Methane Potential of Food Waste from Engineering Faculty Cafeteria in Universitas Indonesia. 2015 International Conference on Sustainable Energy Engineering and Application (ICSEEA). (2015)

17. Basaria, P \& Priadi, C. R. Influence of Organic Fraction of Municipal Solid Waste Particle Size on Biogas Production. International Journal of Technology, 7(8), 1431 - 1437. (2016)

18. Martín-González, L., Colturato, L. F., Font, X., \& Vicent, T. Anaerobic co-digestion of the organic fraction of municipal solid waste with FOG waste from a sewage treatment plant: Recovering a wasted methane potential and enhancing the biogas yield. Waste Management, 30(10), 1854-1859. (2010). 
19. Nizami, A. S., \& Murphy, J. D. What Type Of Digester Configurations Should Be Employed To Produce Biomethane From Grass Silage? Renewable and Sustainable Energy Reviews, 14(6), 1558-1568. (2010)

20. Chen, Y., Cheng J.J., \& Creamer K.S. Inhibition of anaerobic digestion process: a review. Bioresource Technology, 99(10):4044-4064. (2008)

21. Martín-González, L., Colturato, L. F., Font, X., \& Vicent, T. Anaerobic co-digestion of the organic fraction of municipal solid waste with FOG waste from a sewage treatment plant: Recovering a wasted methane potential and enhancing the biogas yield. Waste Management, 30(10), 1854-1859. (2010). 